\title{
Pengembangan Website E-Arsip Di Kantor Kelurahan Pabelan
}

\author{
Ari Gunanto, Endah Sudarmilah \\ Program Studi Informatika \\ Universitas Muhammadiyah Surakarta \\ Surakarta, Indonesia \\ arie.g2424@gmail.com, endah.sudarmilah@ums.ac.id
}

\begin{abstract}
Abstraksi-Kantor kelurahan Pabelan adalah kantor penyedia layanan Masyarakat di kelurahan Pabelan yang menyediakan berbagai surat untuk membantu masyarakat di kelurahan Pabelan. Selama ini kantor kelurahan masih menggunakan pengarsipan secara manual yang berbentuk surat yang mana dalam penyediaan surat harus dilakukan secara manual yang akan memperlambat dalam kinerja kantor. Penelitian ini bertujuan untuk mengembangkan sebuah sistem pengarsipan yang mudah, cepat dan tepat dalam menyimpan surat-surat yang masuk ataupun keluar. Pembuatan e-arsip membutuhkan beberapa perangkat untuk membantu dalam pembuatan e-arsip tersebut, seperti sublime text, laptop, XAMPP, google chrome, scanner, printer, operating system. Waterfall model merupakan meode yang dipilih penulis untuk mengembangkan aplikasi ini dengan setiap tahapannya. Hasil dari pembuatan $e$ arsip ini yaitu adanya sistem pengarsipan yang terkomputerisasi sehingga dapat mempermudah pegawai kantor untuk menyimpan dan menyediakan surat yang masuk maupun keluar di kantor tersebut. Tampilan dari e-arsip di kantor kelurahan Pabelan disesuaikan dengan permintaan dari pegawai kantor tersebut. Berdasarkan uji blackbox yang dilakukan terhadap kinerja aplikasi yang dirancang bangun menunjukkan kedua belas poin pengujian sistem valid.
\end{abstract}

Kata Kunci: Arsip Elektronik, Website

\section{Pendahuluan}

Kearsipan merupakan bagian krusial menurut pekerjaan kantor. Setiap pekerjaan pada perkantoran mempunyai data dan fakta yang salah satunya berupa arsip, karena arsip merupakan bukti suatu pekerjaan atau kegiatan. Arsip umumnya diolah secara manual maupun elektronik [1].

Kantor kelurahan Pabelan adalah salah satu kantor pelayanan kependudukan bagi masyarakat. Pejabat desa atau kelurahan adalah pejabat layanan publik yang bertanggung jawab untuk memberikan layanan kepada masyarakat dan membantu para pemimpin desa untuk melakukan tugas mereka [2]. Selama ini kantor kelurahan Pabelan telah melayani masyarakat di wilayah pabelan dalam menyediakan surat-surat untuk membantu masyarakat mendapatkan kebutuhan-kebutuhan seperti Surat Keterangan Catatan
Kepolisian (SKCK), Surat Pengantar Kartu Tanda Penduduk (KTP), dan lebih banyak surat untuk membantu masyarakat. Surat memiliki fungsi yang sangat penting dan dapat digunakan sebagai dokumen karena mereka memiliki bukti tanda tangan [3]. Komunikasi surat-menyurat di kantor pemerintah dan swasta adalah kegiatan yang biasanya dilakukan dalam kehidupan sehari-hari kantor [4].

Suatu kantor baik itu kantor pelayanan masyarakat maupun kantor yang berkaitan dengan data-data kemasyarakatan selalu berusaha untuk menyediakan data secara mudah, cepat dan tepat. Walaupun kantor yang berurusan dengan pelayanan masyarakat sangat banyak data-data yang masuk dan keluar, tetapi kantor harus memberikan pelayanan yang mudah, cepat, dan tepat.

Penulis mencoba untuk mencari solusinya agar kantor kelurahan dapat menyediakan surat-surat dengan mudah, cepat dan tepat. Dengan ini penulis membuat sistem pengarsipan berbasis elektronik yang biasa disebut elektronik arsip [5]. Rifauddin mengungkapkan bahwa di Indonesia, masih banyak lembaga yang tidak mementingkan pengelolaan catatan elektronik, sehingga surat-surat yang dihasilkan muncul dalam bentuk dokumen kertas.

Adanya pengarsipan yang terkomputerisasi diharapkan kantor kelurahan dapat memberikan pelayanan dengan mudah, cepat dan tepat dan juga dapat mempermudah staff kantor untuk menyimpan surat-surat yang diperoleh dari masyarakat. Selain itu juga dapat mempermudah staff kantor untuk mendapatkan surat yang bersangkutan dengan perkantoran seperti surat undangan kecamatan, undangan kabupaten, undangan-undangan dinas lain, undangan lain-lain, undangan sekertariat daerah, pengantar KTP, pengantar Kartu Keluarga (KK), sertifikat bisnis, SKCK, akta kelahiran, akta kematian.

\section{Metode}

Penelitian ini dilakukan di Kantor Kelurahan Pabelan dengan metode pengembangan sistem yang digunakan pada penelitian ini menggunakan sistem System Development Life 
Cycle (SDLC) dengan menggunakan metode waterfall, dengan penjelasan pada Gambar 1 .

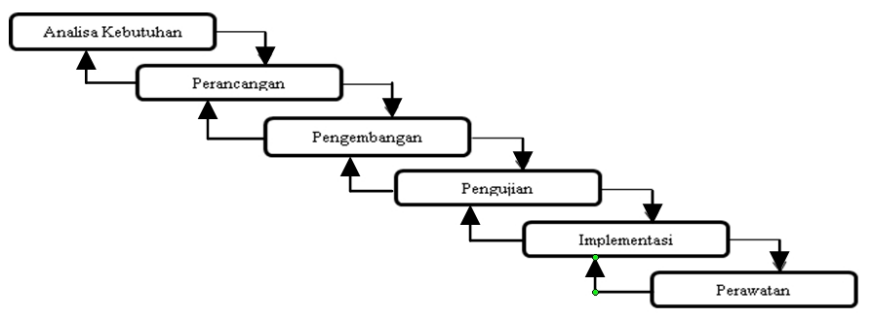

Gambar 1. Metode waterfall

System Development Life Cycle (SDLC) adalah proses logis yang digunakan oleh analis sistem untuk mengembangkan sistem informasi yang melibatkan persyaratan, verifikasi, dan pemilik sistem. Pemodelan dalam pengembangan perangkat lunak adalah sesuatu yang harus dilakukan pada tahap awal rekayasa. Keuntungan menggunakan metode water fall adalah dapat melakukan analisis dan kontrol setiap tahapan, sehingga meminimalkan kemungkinan kesalahan.

\subsection{Analisis Kebutuhan}

Tahap awal analisis kebutuhan adalah penulis melakukan wawancara dan observasi untuk mengumpulkan data dan karakteristik yang diperlukan. Observasi ini dilakukan di Kantor desa Pabelan dengan mengumpulkan data-data pendukung untuk analisis kebutuhan rancang bangun e-arsip. Berdasarkan wawancara yang telah dilakukan, data-data yang diperlukan dalam pembuatan e-arsip yaitu sebagai berikut: surat undangan kecamatan, surat undangan kabupaten, surat undangan sekertaris daerah, pengantar KTP, pengantar KK, sertifikat bisnis, SKCK, akta kelahiran, akta kematian, surat perjalanan dinas. Data dikumpulkan secara langsung melalui cara pengamatan (observasi) langsung ke kantor kelurahan Pabelan.

Analisis berikutnya adalah analisis kebutuhan untuk membuat e-arsip yang mana kebutuhan ini sangat penting untuk mendukung pembuatan e-arsip yang berupa kebutuhan hardware, software, brainware. Tabel 1 adalah tabel analisis kebutuhan.

TABEL 1. ANALISIS KEBUTUHAN

\begin{tabular}{|c|c|c|}
\hline Kebutuhan & Pengertian & Alat \\
\hline Hardware & $\begin{array}{l}\text { Kumpulan-kumpulan komponen } \\
\text { fisik yang menyusun perangkat } \\
\text { komputer serta komponen } \\
\text { komputer/elektronik r yang } \\
\text { mempunyai bentuk fisik. }\end{array}$ & $\begin{array}{l}\text { - komputer/laptop } \\
\text { - scanner } \\
\text { - printer }\end{array}$ \\
\hline Software & $\begin{array}{llr}\text { Kumpulkan line code } & \text { yang } \\
\text { dijalankan komputer } & \text { untuk } \\
\text { melakukan tugas tertentu. } & \end{array}$ & $\begin{array}{l}\text { - } \text { OS Microsoft } \\
\text { Windows 7,8,10 } \\
\text { - XAMPP } \\
\text { - Sublime text editor } \\
\text { - Notepad ++ } \\
\text { - } \text { Google chrome }\end{array}$ \\
\hline Brainware & $\begin{array}{l}\text { Orang yang menggunakan atau } \\
\text { memanfaatkan komputer. }\end{array}$ & $\begin{array}{l}\text { - Operator } \\
\text { - User/Pengguna } \\
\text { - Programer }\end{array}$ \\
\hline
\end{tabular}

\subsection{Perancangan}

Tahapan perancangan atau desain merupakan tahapan dari desain use case, activity diagram dan perancangan database. Tujuan dari fase desain adalah untuk menguraikan pekerjaan yang harus dilakukan dan cara membuat sistem [6]. Berikut adalah rancangan dari sistem e-arsip di kantor kelurahan Pabelan.

\subsubsection{Use Case Diagram (UCD)}

Use Case Diagram digunakan untuk menggambarkan interaksi antara sistem dan aktor. Angka ini hanya untuk deskripsi global dari beberapa elemen digunakan [7]. Aktor merupakan admin yang dapat memanajemen user, memasukan surat, mengubah surat, menghapus surat, dan mencetak surat. Aktor kedua yang merupakan user yang hanya dapat melihat surat saja. UCD pada e-arsip ini dijelaskan pada Gambar 2.

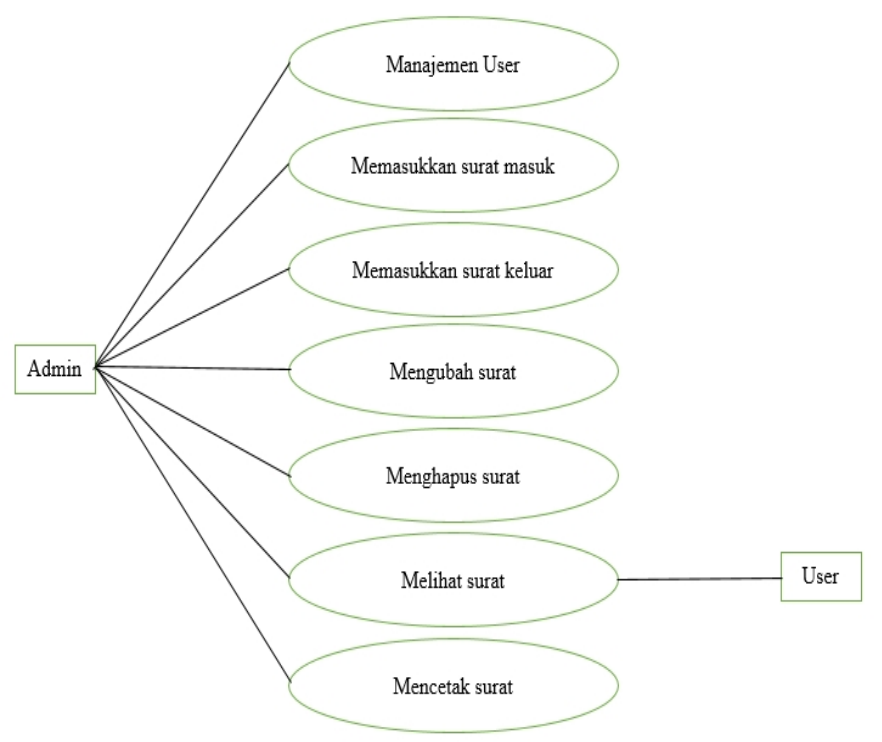

Gambar 2. UCD untuk Admin dan User

\subsubsection{Activity Diagram (AD)}

Activity Diagram merupakan diagram alur kegiatan (aktivitas) penggunaan (proses, logika, proses bisnis, dan hubungan) antara aktor dan alur kerja) use case [7]. Penjelasan global AD dalam alur kerja sistem e-arsip ini diagram aktivitas menjelaskan aktivitas dari satu aktivitas ke aktivitas lainnya, seperti proses login admin, hingga mencetak berkas melalui sistem. Diagram aktivitas e-arsip diperlihatkan pada Gambar 3. 


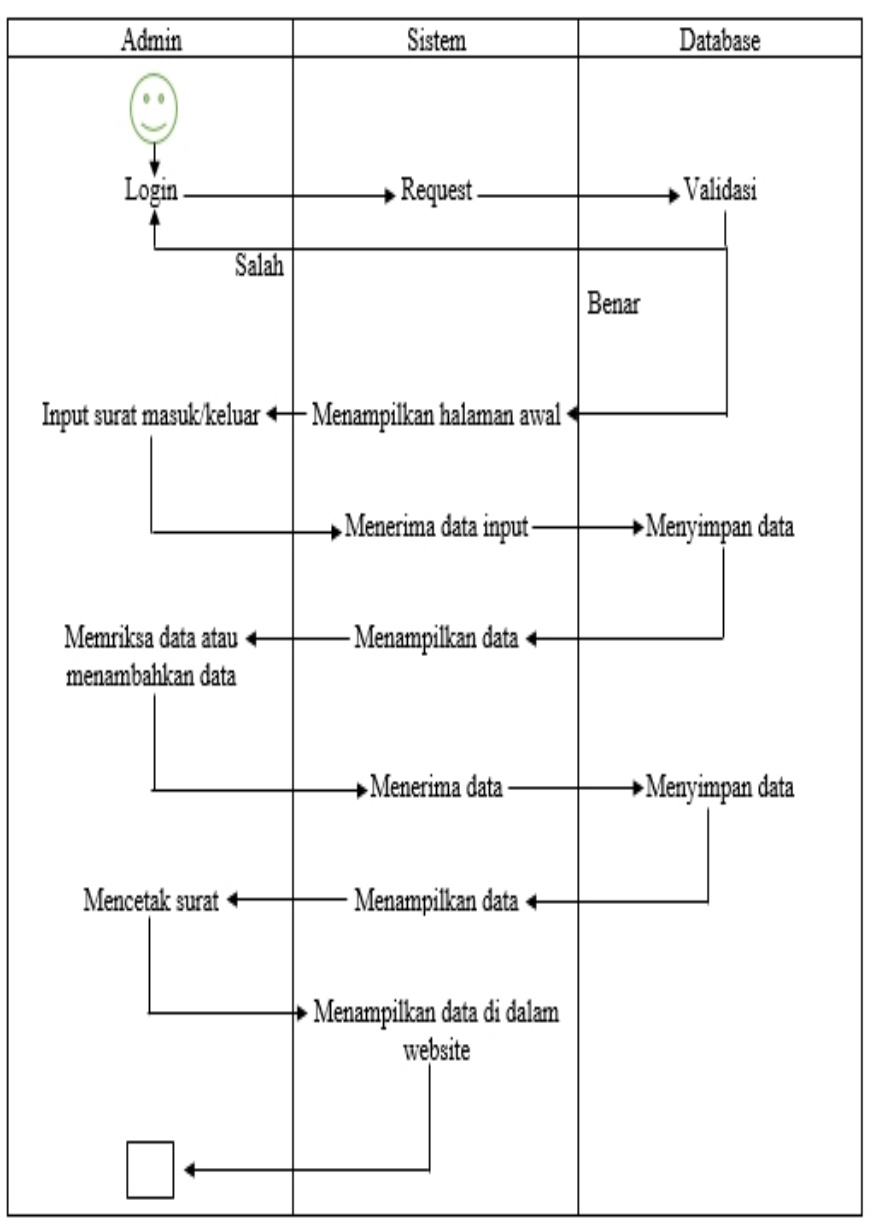

Gambar 3. Activity Diagram

\subsubsection{Rancangan Database}

Database atau basis data adalah kumpulan file yang saling terkait dan interaktif, hubungannya ditunjukkan oleh kunci dari setiap file yang ada [8].

Rancangan database e-arsip ini menggunakan basis data MySql PhpMyAdmin (Strucctured Query Language) dengan satu buah basis data dengan tabel untuk menyimpan data. MySql ialah implementasi sistem manajemen basis data relasional (RDBMS) [9]. Database dalam e-arsip ini terdiri dari 14 tabel, yaitu tbl_fa, tbl_jenlur, tbl_jenma, tbl_nav, tbl_online, tbl_permission, tbl_privilages, tbl_scan_sulur, tbl_scan_suma, tbl_suma, tbl_sulur, tbl_user, tbl_user_desc, tbl_user_log. Rancangan database dijelaskan pada Gambar 4.
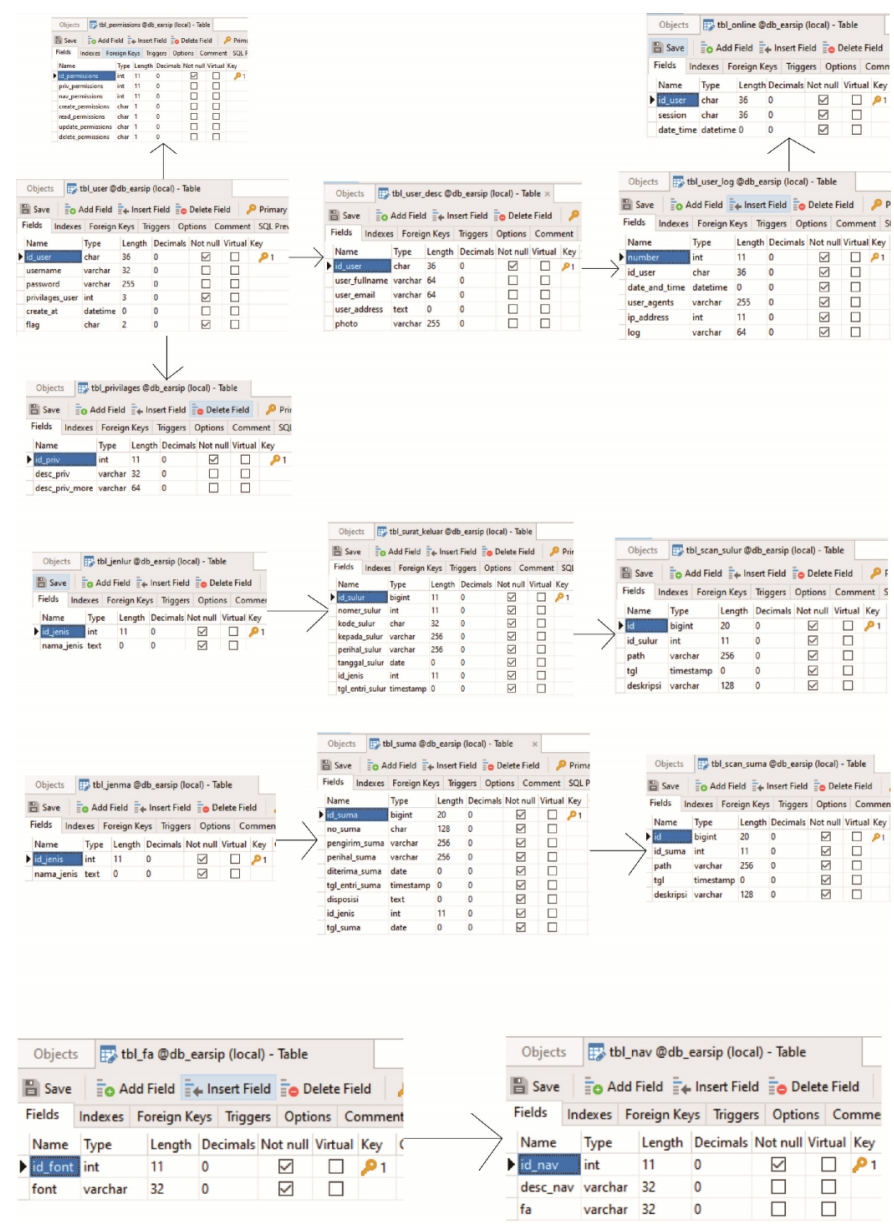

Gambar 4. Perancangan Database

\subsubsection{Rancangan Tampilan}

Rancangan tampilan ini digunakan sebagai pedoman hasil akhir dari e-arsip di kantor kelurahan Pabelan. Rancangan tampilan ini terdiri dari rancangan halaman utama dimana terdapat data dashboard, user, surat masuk, surat keluar, privilages, jenis surat masuk, jenis surat keluar. Penampilan rancangan $e$-arsip ini ditunjukkan pada Gambar 5.

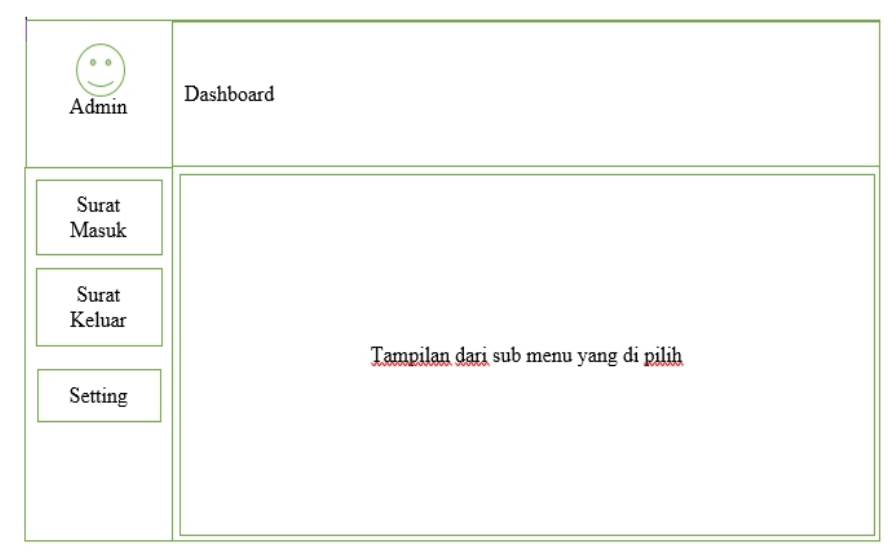

Gambar 5. Rancangan Tampilan 


\subsection{Pengembangan}

Tahap coding merupakan suatu aktifitas yang bertujuan membuat sebuah program atau menerapkan hasil rancangan website. Tahap ini adalah implementasi line code menggunakan bahasa php, database MySql, dan sublime text editor untuk membangun sistem. PHP adalah pemrograman interpreter, proses mengubah satu baris kode menjadi kode mesin. Ketika garis kode dieksekusi, komputer dapat memahami kode tersebut [10].

\subsection{Pengujian Sistem}

Fase pengujian sistem adalah aktivitas yang menguji prosedur yang diselesaikan, terlepas dari apakah prosedur memenuhi harapan. Metode yang digunakan adalah metode black box untuk menemukan sistem yang memenuhi harapan.

\subsection{Implementasi Sistem}

Implementasi sistem adalah tahap akhir dari penerapan sistem di kantor kelurahan Pabelan.

\subsection{Perawatan}

Perawatan e-arsip dilakukan oleh kantor kelurahan setelah sistem sudah digunakan langsung oleh kantor kelurahan.

\section{Hasil Dan Pembahasan}

\subsection{Hasil}

Sitem pengarsipan yang dihasilkan pada penelitian ini berupa penyediaan surat-surat yang telah diterima oleh kantor kelurahan Pabelan yang berbentuk surat elektronik, sehingga dapat mempercepat penyediaan surat-surat.

\subsubsection{Halaman Login}

Fungsi dari halaman login digunakan untuk masuk ke dalam halaman sistem dengan mengisi username dan password. Halaman login ditunjukkan pada Gambar 6.

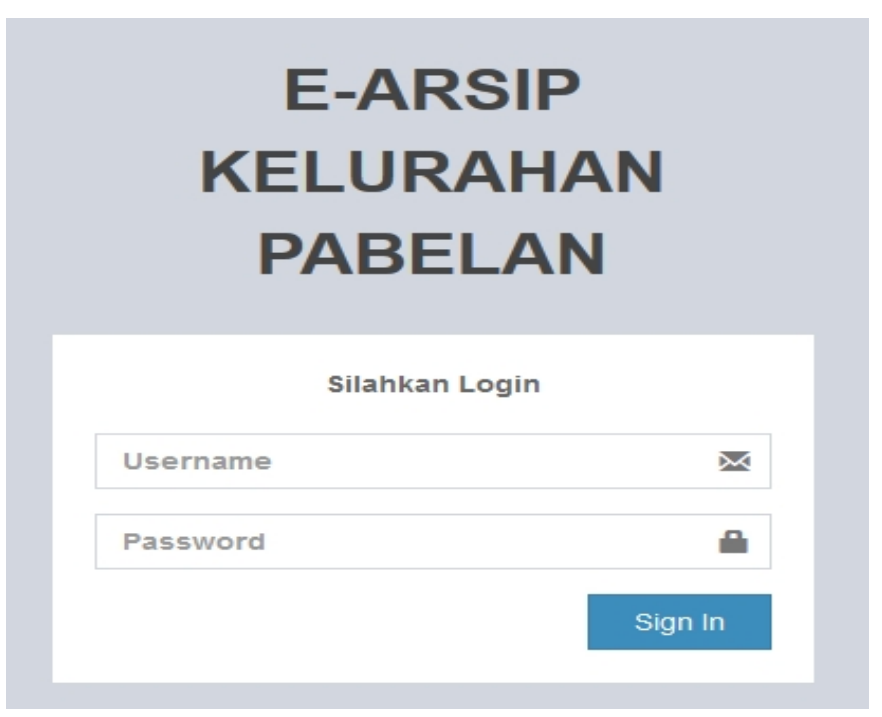

Gambar 6. Tampilan halaman login

\subsubsection{Halaman Tampilan Utama}

Halaman tampilan utama memiliki beberapa macam pilihan sub menu dan main menu yang fungsinya untuk mengarahkan kepada fitur yang akan dipilih seperti master surat, dan setting. Halaman tampilan utama dari website $e$ arsip dapat dilihat pada gambar 7 .

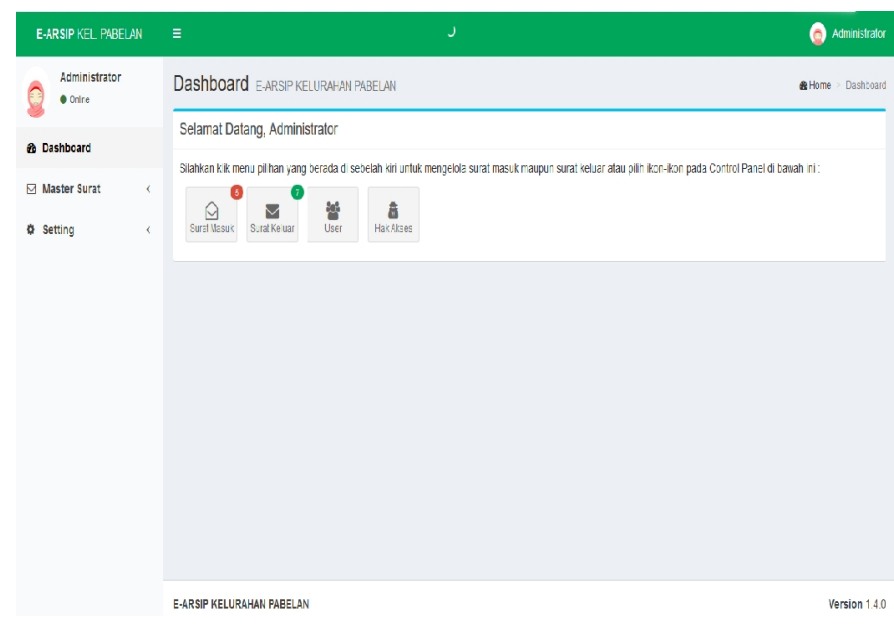

Gambar 7. Tampilan halaman utama

\subsubsection{Halaman Surat Masuk}

Halaman surat masuk digunakan untuk melihat informasi surat masuk yang telah diinput oleh admin, yang mana data dari setiap surat yang diinput dapat dilihat kembali dan di download sesuai dengan kebutuhan. Tampilan dari halaman surat masuk dapat dilihat pada Gambar 8.

\begin{tabular}{|c|c|c|c|}
\hline \multicolumn{3}{|c|}{ Us localhost/127.0.0.1/db_earsip $X$} & E-ARSIP KELURAHAN PABELAN $\times$ \\
\hline & $\rightarrow$ C & & (1) (i) localhost/e_arsip/surat/masuk \\
\hline \multicolumn{3}{|c|}{ E-ARSIP KEL. PABELAN } & $\equiv$ \\
\hline \multirow{2}{*}{\multicolumn{2}{|c|}{ Administrato }} & & Arsip Surat Masuk Preview \\
\hline & & Dashboard & Pilih Jenis Surat Dulu \\
\hline \multirow{2}{*}{$\square$} & \multirow{2}{*}{ Master Surat } & \multirow{2}{*}{$\checkmark$} & Pilih Jenis Surat \\
\hline & & & Pilih Jenis Surat \\
\hline & Surat Masuk & 5 & UNDANGAN KECAMATAN \\
\hline O & Surat Keluar & 7 & UNDANGAN KABUPATEN \\
\hline \multirow{3}{*}{\multicolumn{2}{|c|}{ Setting }} & \multirow{3}{*}{$<$} & UNDANGAN DINAS LAIN \\
\hline & & & UNDANGAN LAIN-LAIN \\
\hline & & & UNDANGAN SEKRETARIAT DAERAH \\
\hline
\end{tabular}

\subsubsection{Halaman Surat Keluar}

Halaman surat keluar digunakan untuk melihat informasi surat keluar yang telah diinput oleh admin, yang mana data dari setiap surat yang diinput dapat dilihat kembali dan di download sesuai dengan kebutuhan. Tampilan dari halaman surat keluar dapat dilihat pada Gambar 9. 


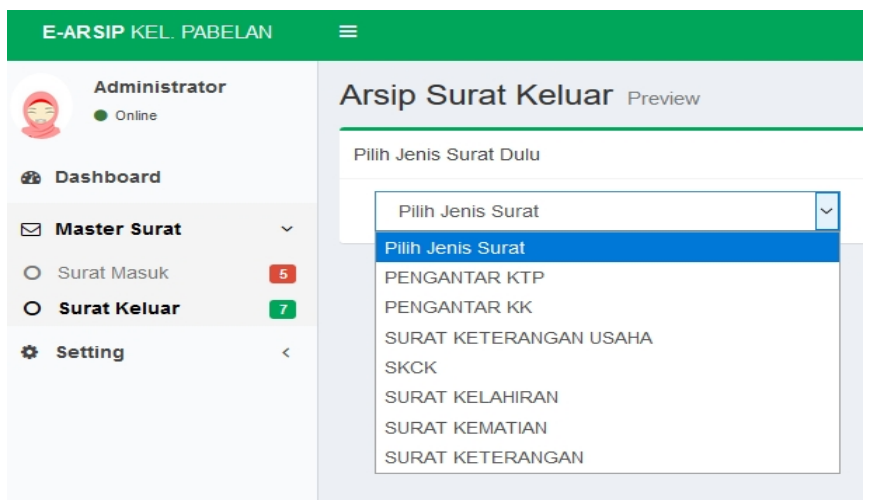

Gambar 9. Tampilan surat keluar

\subsubsection{Halaman input Surat Masuk}

Penginputan data surat masuk ini diisi oleh admin yang telah berhasil login dengan memasukkan beberapa data ke dalam e-arsip. Tampilan dari halaman input surat masuk dapat dilihat pada Gambar 10.

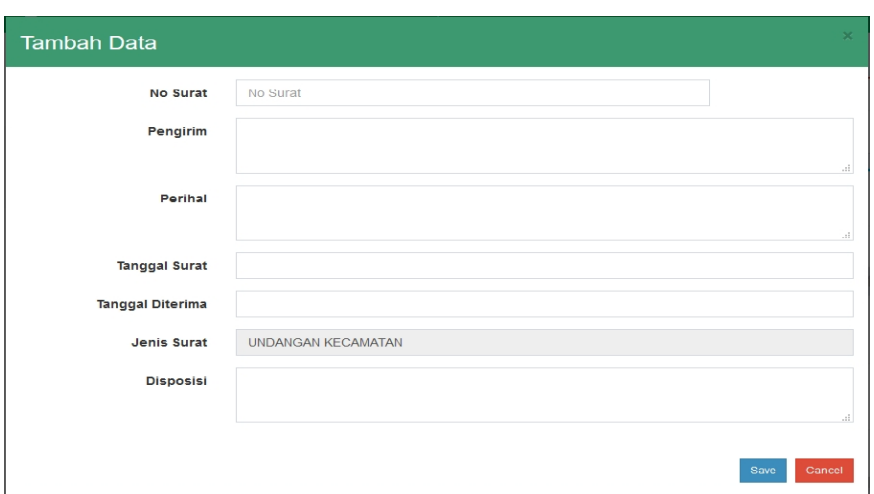

Gambar 10. Tampilan input surat masuk

\subsubsection{Halaman input Surat Keluar}

Penginputan data surat keluar ini diisi oleh admin yang telah berhasil login dengan memasukkan beberapa data kedalam e-arsip. Tampilan dari halaman input surat keluar dapat dilihat pada Gambar 11.

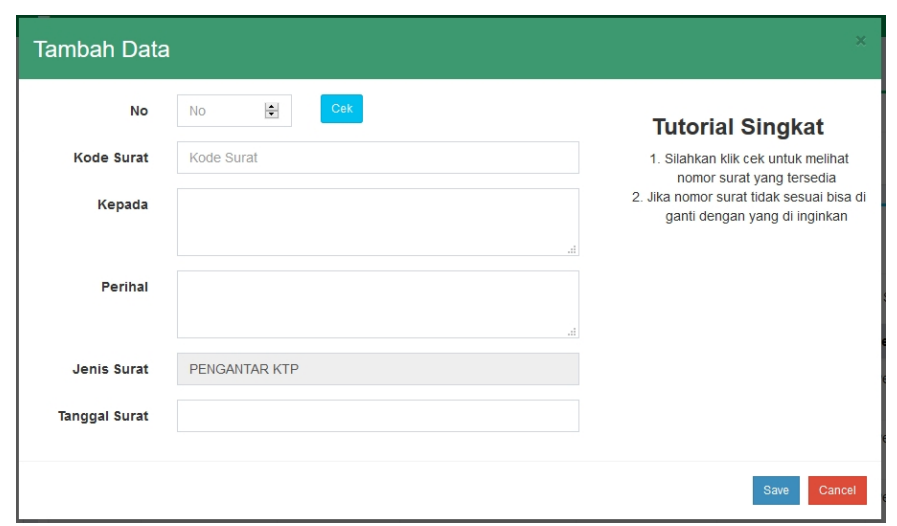

Gambar 11. Tampilan input surat keluar

\subsubsection{Halaman upload data surat}

Upload data surat berguna untuk menambahkan data ke dalam surat tertentu yang bersangkutan dengan surat tersebut, dan data yang bisa di upload berupa data yang bertipe pdf, jpg dan png. Tampilan dari halaman upload dapat dilihat pada Gambar 12.

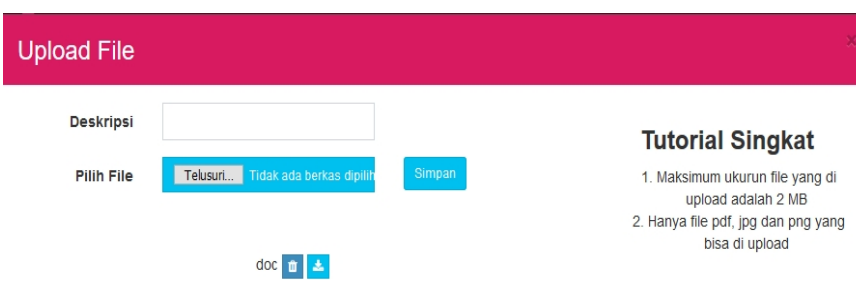

Gambar 12. Tampilan upload data

\subsubsection{Halaman Setting User}

Halaman ini digunakan untuk mengontrol user seperti menambahkan id, menghapus id, mengganti password. Tampilan dari halaman setting user dapat dilihat pada Gambar 13.

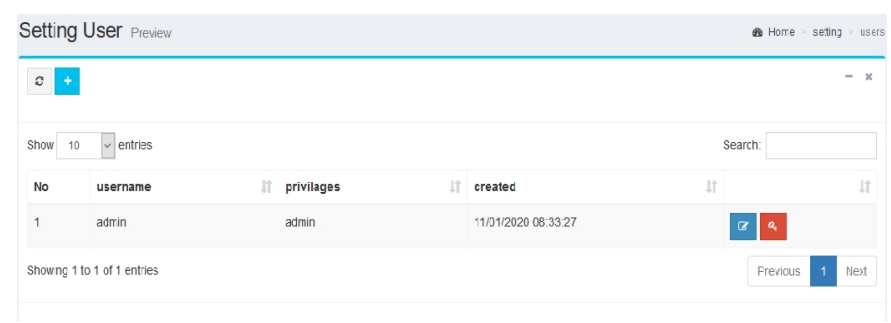

Gambar 13. Tampilan setting user

\subsubsection{Halaman Setting Privilege}

Halaman ini digunakan untuk membedakan hak akses user yang telah login ke dalam e-arsip dan digunakan untuk mengganti hak akses sesuai kebutuhan. Tampilan dari halaman setting privilege dapat dilihat pada Gambar 14.

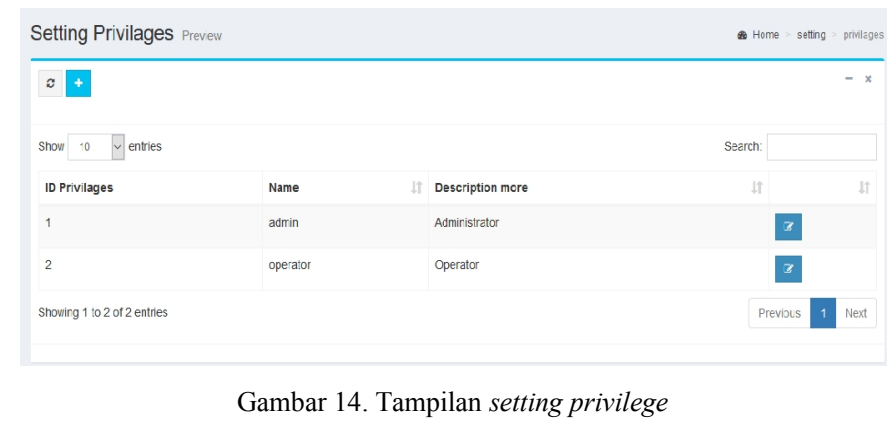

\subsubsection{Halaman Jenis Surat Masuk dan Keluar}

Halaman ini digunakan untuk menambahkan jenis surat masuk ke dalam e-arsip untuk memisahkan surat yang 
berbeda. Tampilan dari halaman jenis surat masuk dan keluar dapat dilihat pada Gambar 15 dan 16.

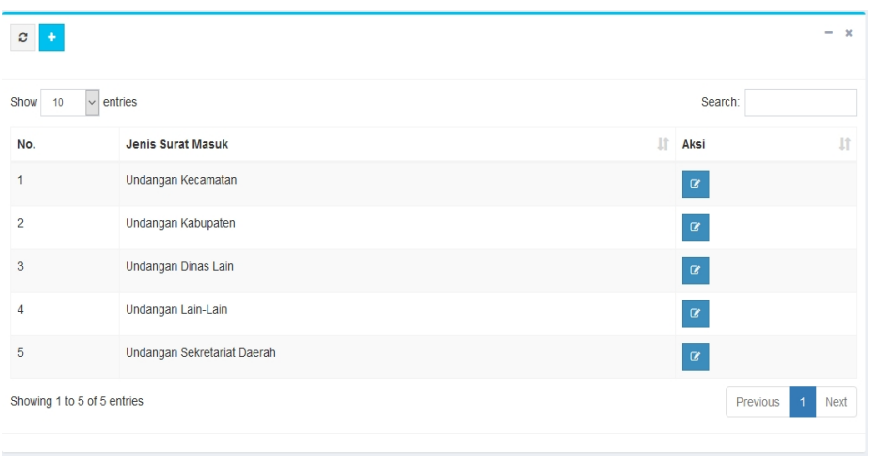

Gambar 15. Tampilan jenis suarat masuk

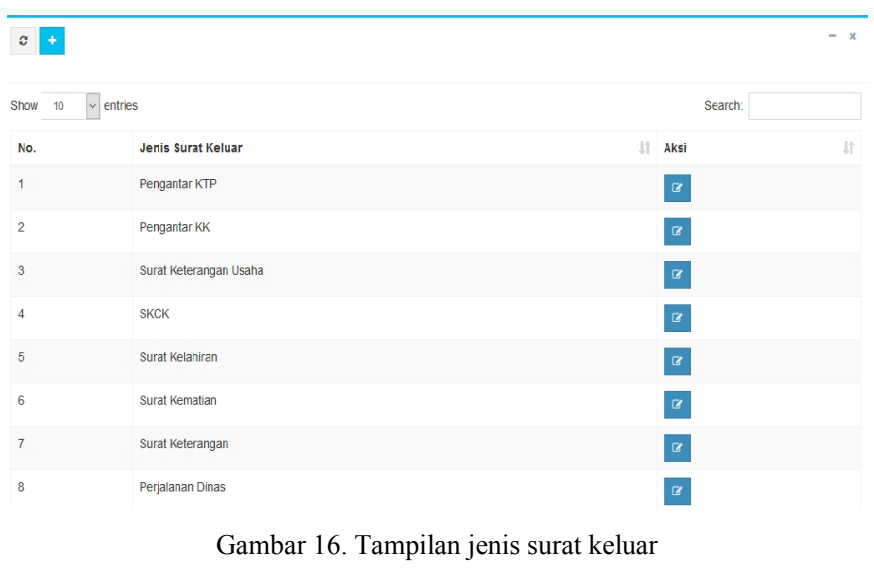

\subsubsection{Halaman awal dari website}

Halaman ini digunakan untuk memberikan informasi kepada selain admin dan operator untuk mencari surat-surat yang dibutuhkan. Tampilan halaman awal dapat dilihat pada Gambar 17.

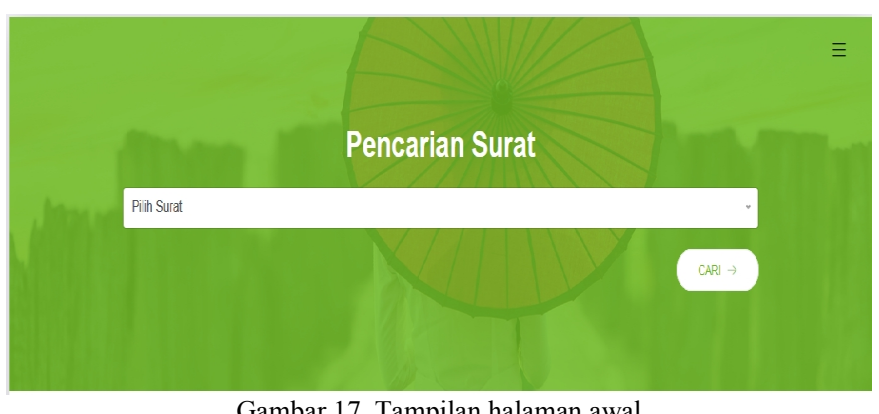

Gambar 17. Tampilan halaman awal

\subsection{Pengujian dan Pembahasan}

Pengujian black-box adalah pengujian terhadap fungsi operasional e-arsip. Pendekatan ini biasanya dilakukan oleh penguji yang tidak ikut serta dalam pengkodean, namun juga sering kali dilakukan oleh orang yang melakukan pengkodean, untuk menuliskan laporan kepada pengguna. Black-box testing juga memberikan informasi-informasi tentang pengujian sistematis seperti pengujian username, password, upload, dll. Tabel 2 adalah tabel hasil pengujian black-box.
TABEL 2. Hasil Pengujian BLACK-BOX

\begin{tabular}{|c|c|c|c|c|c|}
\hline No & $\begin{array}{c}\text { Skenario } \\
\text { Pengujian }\end{array}$ & Test Case & $\begin{array}{l}\text { Hasil Yang } \\
\text { Diharapkan }\end{array}$ & $\begin{array}{c}\text { Hasil } \\
\text { Pengujian }\end{array}$ & Status \\
\hline 1 & $\begin{array}{l}\text { Username dan } \\
\text { password di } \\
\text { kosongkan, } \\
\text { lalu langsung } \\
\text { mengklik } \\
\text { tombol sign in. }\end{array}$ & $\begin{array}{l}\text { Username } \\
\text { :- } \\
\text { Password: } \\
\text { - }\end{array}$ & $\begin{array}{l}\text { Sistem akan } \\
\text { menolak dan } \\
\text { memberitahu } \\
\text { untuk mengisi } \\
\text { username dan } \\
\text { password. }\end{array}$ & $\begin{array}{c}\text { Sesuai } \\
\text { harapan }\end{array}$ & Valid \\
\hline 2 & $\begin{array}{l}\text { Diisi dengan } \\
\text { username saja } \\
\text { dan } \\
\text { mengosongkan } \\
\text { password, lalu } \\
\text { langsung } \\
\text { mengklik } \\
\text { tombol sign in. }\end{array}$ & $\begin{array}{l}\text { Username } \\
\text { : admin } \\
\text { Password: } \\
\text { - }\end{array}$ & $\begin{array}{c}\text { Sistem akan } \\
\text { menolak login } \\
\text { dan } \\
\text { memberitahu } \\
\text { untuk mengisi } \\
\text { password. }\end{array}$ & $\begin{array}{c}\text { Sesuai } \\
\text { harapan }\end{array}$ & Valid \\
\hline 3 & $\begin{array}{c}\text { Disi dengan } \\
\text { password saja } \\
\text { dan } \\
\text { mengosongkan } \\
\text { username, lalu } \\
\text { langsung } \\
\text { mengklik } \\
\text { tombol sign in. }\end{array}$ & $\begin{array}{l}\text { Username } \\
:- \\
\text { Password } \\
\text { : admin }\end{array}$ & $\begin{array}{c}\text { Sistem akan } \\
\text { menolak login } \\
\text { dan } \\
\text { memberitahu } \\
\text { untuk mengisi } \\
\text { username. }\end{array}$ & $\begin{array}{c}\text { Sesuai } \\
\text { harapan }\end{array}$ & Valid \\
\hline 4 & $\begin{array}{c}\text { Mengisi } \\
\text { username } \\
\text { dengan benar } \\
\text { namun } \\
\text { password } \\
\text { salah, lalu } \\
\text { langsung } \\
\text { mengklik } \\
\text { tombol sign in. }\end{array}$ & $\begin{array}{l}\text { Username } \\
\text { : admin } \\
\text { (benar). } \\
\text { Password: } \\
1234 \\
\text { (salah). }\end{array}$ & $\begin{array}{c}\text { Sistem akan } \\
\text { menolak login } \\
\text { dan } \\
\text { memberitahu } \\
\text { bahwa } \\
\text { Password salah. }\end{array}$ & $\begin{array}{c}\text { Sesuai } \\
\text { harapan }\end{array}$ & Valid \\
\hline 5 & $\begin{array}{c}\text { Mengisi } \\
\text { password } \\
\text { dengan benar } \\
\text { namun } \\
\text { username } \\
\text { salah, lalu } \\
\text { langsung } \\
\text { mengklik } \\
\text { tombol sign in. }\end{array}$ & $\begin{array}{l}\text { Username } \\
\text { : Corona } \\
\text { (salah). } \\
\text { Password: } \\
\text { admin } \\
\text { (Benar). }\end{array}$ & $\begin{array}{c}\text { Sisitem akan } \\
\text { menolak login } \\
\text { dan } \\
\text { memberitahu } \\
\text { bahwa } \\
\text { username atau } \\
\text { password salah. }\end{array}$ & $\begin{array}{c}\text { Sesuai } \\
\text { harapan }\end{array}$ & Valid \\
\hline 6 & $\begin{array}{c}\text { Mengisi } \\
\text { username } \\
\text { dengan benar } \\
\text { dan password } \\
\text { dengan benar, } \\
\text { lalu langsung } \\
\text { mengklik } \\
\text { tombol sign in. }\end{array}$ & $\begin{array}{l}\text { Username } \\
\text { : admin } \\
\text { (Benar). } \\
\text { Password: } \\
\text { admin } \\
\text { (Benar). }\end{array}$ & $\begin{array}{c}\text { Maka akan } \\
\text { langsung masuk } \\
\text { kedalam web } e- \\
\text { arsip. }\end{array}$ & $\begin{array}{c}\text { Sesuai } \\
\text { harapan }\end{array}$ & Valid \\
\hline 7 & $\begin{array}{l}\text { Mengetik surat } \\
\text { yang akan } \\
\text { dicari di dalam } \\
\text { surat masuk. }\end{array}$ & $\begin{array}{c}\text { Search: } \\
\text { Undangan } \\
\text { Kecamata } \\
\text { n }\end{array}$ & $\begin{array}{l}\text { Otomatis } \\
\text { memunculkan } \\
\text { surat yang } \\
\text { dicari. }\end{array}$ & $\begin{array}{c}\text { Ada } \\
\text { beberapa } \\
\text { surat yang } \\
\text { akan muncul } \\
\text { sesuai } \\
\text { dengan yang } \\
\text { dicari secara } \\
\text { otomatis. }\end{array}$ & Valid \\
\hline 8 & $\begin{array}{l}\text { Mengetik surat } \\
\text { yang akan } \\
\text { dicari di dalam } \\
\text { surat keluar. }\end{array}$ & $\begin{array}{l}\text { Search: } \\
\text { Pengantar } \\
\text { KTP }\end{array}$ & $\begin{array}{l}\text { Otomatis } \\
\text { memunculkan } \\
\text { surat yang } \\
\text { dicari. }\end{array}$ & $\begin{array}{c}\text { Ada } \\
\text { beberapa } \\
\text { surat yang } \\
\text { akan muncul } \\
\text { sesuai } \\
\text { dengan yang } \\
\text { dicari secara } \\
\text { otomatis. }\end{array}$ & Valid \\
\hline 9 & $\begin{array}{l}\text { Mengunggah } \\
\text { berkas sesuai }\end{array}$ & $\begin{array}{l}\text { Mengung } \\
\text { gah }\end{array}$ & $\begin{array}{c}\text { Maka akan ter } \\
\text { upload dan }\end{array}$ & $\begin{array}{c}\text { Sesuai } \\
\text { harapan }\end{array}$ & Valid \\
\hline
\end{tabular}




\begin{tabular}{|c|c|c|c|c|c|}
\hline & $\begin{array}{c}\text { dengan format, } \\
\text { lalu mengklik } \\
\text { tombol save. }\end{array}$ & $\begin{array}{l}\text { berkas } \\
\text { dengan } \\
\text { format } \\
\text { png. }\end{array}$ & $\begin{array}{c}\text { tersimpan. Dan } \\
\text { akan } \\
\text { memberitahuka } \\
\text { n bahwa file } \\
\text { sukses } \\
\text { diungguh. }\end{array}$ & $\begin{array}{c}\text { success } \\
\text { upload suce }\end{array}$ & \\
\hline 10 & $\begin{array}{c}\text { Mengunggah } \\
\text { berkas sesuai } \\
\text { dengan format } \\
\text { yang salah, } \\
\text { lalu mengklik } \\
\text { tombol save. }\end{array}$ & $\begin{array}{l}\text { Mengung } \\
\text { gah } \\
\text { berkas } \\
\text { dengan } \\
\text { format } \\
\text { mp3. }\end{array}$ & $\begin{array}{c}\text { Maka akan } \\
\text { tertolak. Dan } \\
\text { memberitahuka } \\
\text { n eror, } \\
\text { dikarenakan file } \\
\text { yang diunggah } \\
\text { tidak sesuai } \\
\text { syarat yang } \\
\text { ditentukan. } \\
\end{array}$ & $\begin{array}{l}\text { Sesuai } \\
\text { harapan }\end{array}$ & Valid \\
\hline 11 & $\begin{array}{c}\text { Menghapus } \\
\text { salah satu surat } \\
\text { secara penuh. }\end{array}$ & $\begin{array}{l}\text { Delete } \\
\text { File }\end{array}$ & $\begin{array}{c}\text { Maka akan } \\
\text { muncul } \\
\text { pemberitahuan } \\
\text { untuk } \\
\text { memastikan } \\
\text { apakah benar } \\
\text { operator ingin } \\
\text { menghapus data } \\
\text { tersebut }\end{array}$ & $\begin{array}{c}\text { Sesuai } \\
\text { harapan }\end{array}$ & Valid \\
\hline 12 & $\begin{array}{c}\text { Mengganti } \\
\text { atau mengedit } \\
\text { username dan } \\
\text { password. }\end{array}$ & $\begin{array}{l}\text { Menggant } \\
\text { i } \\
\text { username: } \\
\text { admin1 } \\
\text { Password: } \\
\text { admin1 } \\
\end{array}$ & $\begin{array}{l}\text { Maka data akan } \\
\text { terganti. }\end{array}$ & $\begin{array}{l}\text { Sesuai } \\
\text { harapan }\end{array}$ & Valid \\
\hline
\end{tabular}

Berdasarkan hasil pengujian black box pada Tabel 2, dapat disimpulkan bahwa dari 12 poin yang diujikan hasilnya semua baik dan sesuai dengan apa yang diharapkan dan berjalan sesuai fungsinya. Sistem e-arsip kelurahan pabelan ini berjalan dengan baik secara fungsional setelah beberapa kesalahan dan penambahan coding. Namun tidak menutup kemungkinan kesalahan terjadi dan diperlukan perbaikan.

\section{Penutup}

Penelitian tentang e-arsip kantor kelurahan Pabelan berbasis web ini dikembangkan untuk mempermudah admin dalam mengontrol surat di kelurahan. Pembuatan e-arsip di kantor kelurahan Pabelan ini tentunya memiliki beberapa kendala teknis ataupun non-teknis seperti beberapa permintaan yang belum sesuai dengan keinginan dari beberapa pegawai kantor tersebut dan kendala pada kesiapan perangkat keras yang kurang memadai. Berdasarkan hasil yang diperoleh dari pengujian black box dengan 12 poin yang diujikan semua valid. Hasil dari pengujian dapat disimpulkan bahwa e-arsip kelurahan Pabelan menciptakan efisiensi dalam melakukan penyimpanan berbagai surat di kantor kelurahan Pabelan.

\section{DAFTAR PUSTAKA}

[1] Amalia, An Nisa Nur. dkk. 2019. Implementasi E-Document Dalam Pengelolaan Surat Masuk dan Keluar (Studi Kebijakan UU No. 11 Tentang Informasi dan Transaksi Elektronik di Bagian Umum Balai Kota Malang, Jawa Timur). Malang: Universitas Islam Malang.

[2] Ismah, Ariqotul. 2019. Penilaian Kinerja Perangkat Desa Pebelan Kecamatan Kartasura Kabupaten Sukoharjo Tahun 2019. Surakarta: Universitas Muhammadiyah Surakarta.

[3] Kartini. 2017. Sistem Informasi Administrasi Pengelolaan Surat di Organisasi Berbasis WEB. Surakarta: Universitas Muhammadiyah Surakarta.

[4] Faisah, Nur. 2018. Analisis Kesalahan Berbahasa Indonesia Dalam Surat-Menyurat Di Kantor Kelurahan Layana Indah. Palu: FKIP Universitas Tadulako.

[5] Rifauddin, Machsun. 2016. Pengelolaan Arsip Elektronik Berbasis Teknologi. Yogyakarta: Universitas Islam Negeri Sunan Kalijaga.

[6] Salsabila, Hanif., dan Endah Sudarmilah. Sistem Informasi Simpan Pinjam di Koprasi Pendidikan Wonogiri. Surakarta: Universitas Muhammadiyah Surakarta.

[7] Mulyani, Sri. 2016. Analisis dan Perancangan Sistem Informasi Manajemen Keuangan Daerah. Bandung: Abdi Sistematika.

[8] Sovia, Rini., dan Jimmy Febio. 2011. Membangun E-Library Menggunakan HTML, PHP Script, dan MySql Database. Jambi: STIKOM Dinamika Bangsa.

[9] Aziz, Berkah Akbar Nuryumil. dkk. 2019. Sistem Informasi Pengelolaan Surat Masuk dan Surat Keluar Jurusan Elektro Politeknik Negri Malang Berbasis Web Melalui Jaringan Internet Polinema. Malang: Politeknik Negri Malang.

[10] Ghozi, Muhammad., dan Dedy Irfan. 2018. Pengembangan Sistem Informasi Manajemen Arsip dan Disposisi Surat Berbasis Web di BPN Kota Padang. Padang: Universitas Negeri Padang. 